\title{
Triassic conodonts from Svalbard and their Boreal correlations
}

\author{
Hans Arne Nakrem, ${ }^{1}$ Michael J. Orchard, ${ }^{2}$ Wolfgang Weitschat, ${ }^{3}$ Mark W. Hounslow, ${ }^{4}$ Tyler W. Beatty ${ }^{5}$ \& \\ Atle Mørk ${ }^{6,7}$ \\ 1 Natural History Museum, University of Oslo, P.O. Box 1172 Blindern, NO-0318 Oslo, Norway \\ 2 Geological Survey of Canada, 101-605 Robson Street, Vancouver, BC V6B 5J3, Canada \\ 3 Geological-Palaeontological Institute and Museum, University of Hamburg, Bundesstrasse 55, DE-20146 Hamburg, Germany \\ 4 Centre for Environmental Magnetism and Palaeomagnetism, Geography, Lancaster Environment Centre, Lancaster University, Bailrigg, Lancaster, \\ LA1 4YQ, UK \\ 5 Department of Geoscience, University of Calgary, 2500 University Drive, NW Calgary, Alberta, T2N 1N4, Canada \\ 6 SINTEF Petroleum Research, NO-7465 Trondheim, Norway \\ 7 Department of Geology and Mineral Resources Engineering, Norwegian University of Sciences and Technology, NO-7491 Trondheim, Norway
}

\section{Keywords}

Arctic; biostratigraphy; Canada; conodonts; Svalbard; Triassic.

\section{Corresponding author}

Hans Arne Nakrem, Natural History Museum, University of Oslo, P.O. Box 1172 Blindern, NO-0318 Oslo, Norway. E-mail:

h.a.nakrem@nhm.uio.no

doi:10.1111/j.1751-8369.2008.00076.x

\begin{abstract}
Conodont faunas are described from Triassic sections of Svalbard, and their occurrences are locally correlated with established ammonoid zones. With a synthesis of previous conodont-based publications, the current work presents a taxonomically up-to-date compilation of conodont data for the Triassic of Svalbard that is used to construct a conodont-based biochronology, indexed to the current lithostratigraphic nomenclature. Twenty-eight taxa spanning the earliest Griesbachian to the earliest Carnian are presented in a range chart. The examined conodont faunas are correlated with well-established conodont zonations of the Canadian Arctic, and in turn also form the basis for regional correlations.
\end{abstract}

In the Svalbard Archipelago, Triassic strata are well exposed and are the subject of numerous stratigraphic, palaeontologic and geochemical studies. Previously, fossil collections were described from units identified in local terminologies, but in the present contribution we follow the lithostratigraphic nomenclature of Mørk, Dallmann et al. (1999), and refer older descriptions to this. This paper represents a synthesis of previous conodont-based work, and presents a taxonomically up-to-date compilation of conodont data for the Triassic. These data are herein used to construct a conodont-based biochronology, indexed to current lithostratigraphic nomenclature (i.e., Mørk, Dallmann et al. 1999), forming the basis for regional correlations.

The Triassic succession of Svalbard (Fig. 1) is dominated by clastic sediments. In the Lower and Middle Triassic of western Spitsbergen, shale and sandstone form upward coarsening sequences representing deposition in coastal, deltaic and shallow marine environments that grade eastwards into shelf deposits (Mørk et al. 1982). In the Late Triassic the main sediment input shifted to the south-east, and prodelta sediments prograded over marine shale, and were followed by the deposition of shallow marine to deltaic sandstone, shale and, in some of the eastern locali- ties, coal (Lock et al. 1978; Mørk et al. 1982; Riis et al. 2008 [this issue]). The Triassic basin extended southwards into the region now occupied by the Barents Sea. During the Triassic this basin formed an extensive embayment of the Panthalassa Ocean into the northern margin of the Pangaea supercontinent (Mørk et al. 1992; Riis et al. 2008; Worsley 2008 [this issue]).

Conodonts have been recovered from throughout the Lower and Middle Triassic succession of Svalbard, as well as from the lowermost part of the Upper Triassic. The main focus in the following account is on the Lower and Middle Triassic units: the Vardebukta, Tvillingodden and Bravaisberget formations in the southern and western areas, and the Vikinghøgda and Botneheia formations in the central parts of Spitsbergen (Fig. 2). These formations comprise the Sassendalen Group (Mørk, Dallmann et al. 1999).

\section{Sassendalen Group (Lower and Middle Triassic)}

In western Spitsbergen, Lower and Middle Triassic strata approach $500 \mathrm{~m}$ in thickness. Here, three formations comprise the Sassendalen Group: the Lower Triassic Vardebukta and Tvillingodden formations, and the Middle Triassic Bravaisberget Formation (Fig. 2). These represent 




Fig. 1 Map of Svalbard indicating the localities mentioned in the text. The geology is from Dallmann (1999: fig. 1.04).

an overall progradational succession, with the three formations constituting barrier bar/lagoon, shallow marine bars/storm beds and deltaic lobe environments, respectively (Mørk, Dallmann et al. 1999; Krajewski et al. 2007). Two distinct sandy biosparites serve as marker horizons in this region: the Myalina limestone in the upper part of the Vardebukta Formation, and the Skilisen Bed (the Retzia limestone) in the lower part of the Tvillingodden Formation (Mørk et al. 1982; Mørk, Dallmann et al. 1999). A major transgression in the early Anisian initiated deposition of the Bravaisberget Formation. At Festningen, a limestone conglomerate with brachiopods and bivalves represents the initial transgressive deposits of the Middle Triassic (Hoel \& Orvin 1937; Egorov \& Mørk 2000), whereas elsewhere, poorly indurated shale overlies the siltstone of the underlying formation. A major sediment input from the west resulted in a coarsening upward and prograding succession, so that the open marine shaly lower Passhatten Member of the Bravaisberget Formation is succeeded by sandy delta front sediments of the Somovbreen Member (Mørk et al. 1982; Krajewski et al. 2007).

In Sørkapp Land in the southern part of Spitsbergen, Early Triassic sedimentation was controlled by the 




Fig. 2 Triassic lithostratigraphy of the areas of Svalbard discussed in the text, with published conodont occurrences. The lithostratigraphy is from Mørk, Dallmann et al. (1999).

Sørkapp-Hornsund High, a late Palaeozoic topographic high that was emergent until the mid-Induan (late Griesbachian-Dienerian) (Birkenmajer 1977; Mørk et al. 1982; Nakrem \& Mørk 1991). On this high the Lower Triassic succession is thin ( $<50-\mathrm{m}$ thick), and contains a basal polymict conglomerate that is locally rich in bivalves (Promyalina sp.), and is referred to the Brevassfjellet Bed: this bed defines the base of the Kistefjellet Member of the Vardebukta Formation (Mørk, Dallmann et al. 1999).

In central and eastern Svalbard, the Vikinghøgda Formation (Mørk, Elvebakk et al. 1999) is equivalent to the Vardebukta and Tvillingodden formations in western Spitsbergen, and the Botneheia Formation is a distal equivalent to the Bravaisberget Formation. The Vikinghøgda Formation comprises silty shale and stormgenerated siltstone deposits, with rare carbonate concretions and discrete horizons enriched in bivalves, brachiopods, ammonoids and vertebrate remains. Transgressive beds deposited on an eroded Permian surface occur at two localities on Edgeøya. An early Olenekian ammonoid fauna was collected from one of these beds (i.e., Krokå; WW, pers. obs.), implying that the lower part of the Triassic succession is missing in these eastern areas, as it is in Sørkapp Land. The Botneheia Formation in central and eastern Spitsbergen, and on the eastern islands of Barentsøya and Edgeøya, consists of dark shale with rare thin siltstone beds and calcareous shale (Mørk, Dallmann et al. 1999). In general, these sediments are of marine origin, and are very organic-rich (Mørk \& Bjorøy 1984).

\section{Kapp Toscana Group (from Middle-Upper Triassic transition to Middle Jurassic)}

The Kapp Toscana Group overlies the Sassendalen Group. In Svalbard the contact approximates the LadinianCarnian boundary (Weitschat \& Dagys 1989; Dagys \& Weitschat 1993), but southwards in the Barents Sea the group transition is older (from the base to the late Ladinian) (Mørk, Dallmann et al. 1999). The group, which continues into the Middle Jurassic, contains several condensed sections and hiatuses. The Kapp Toscana Group 
has a composite thickness of up to $475 \mathrm{~m}$ on Svalbard, thickening to over $1000 \mathrm{~m}$ in southern shelf areas (Mørk, Dallmann et al. 1999).

In Svalbard there is an abrupt change from the dark, organic-rich sediment of the Botneheia Formation to grey sediments, with abundant siderite nodules of the overlying Tschermakfjellet Formation (Mørk et al. 1982). The Tschermakfjellet Formation represents a distal prodelta depositional environment, and overlies the Botneheia Formation and, locally, the Bravaisberget Formation, although in the most western areas it is missing (Mørk et al. 1982). The Tschermakfjellet Formation grades up into the De Geerdalen Formation: the formational boundary is defined by the appearance of the first prominent sandstone of the prograding delta (Lock et al. 1978; Mørk et al. 1982; Mørk, Dallmann et al. 1999; Riis et al. 2008).

Biostratigraphically, the boundary between the Kapp Toscana and Sassendalen groups has been the subject of controversy. In the classical view of Frebold (1929a, b), the "Nathorstites beds" belong to the Carnian, and the Middle/Upper Triassic boundary coincides with the change in facies that is coincident with the modern lithostratigraphic group boundary. Buchan et al. (1965) placed the transition between the groups at the top of the Anisian, and subsequently most authors placed it somewhere in the Ladinan (Tozer \& Parker 1968; Lock et al. 1978; Mørk et al. 1982). Korčinskaja (1982) revived Frebold's ideas, and placed the Ladinian/Carnian boundary at the lithostratigraphic group boundary. Observations by Dagys \& Weitschat (1993), especially in the eastern areas of the exposure at Wichebukta and Agardhbukta, supported these ideas. They described a characteristic early Carnian ammonoid and bivalve fauna from immediately above the group boundary, which indicates that the typical change in facies coincides with the Middle/Upper Triassic boundary. Because diagnostic latest Ladinian ammonoids have not been discovered on Svalbard, the authors interpreted a minor break between the Ladinian and Carnian stages. Phosphatic pebble conglomerates at the boundary support this suggestion.

\section{Material and methods}

Material from the Triassic of Milne Edwardsfjellet (Fig. 1) has been processed for the current study. This includes 81 samples from the Vikinghøgda Formation (from the base of the Lusitaniadalen Member and from the upper part of the Vendomdalen Member), the Botneheia Formation and the lowermost part of the Tschermakfjellet Formation. Material mentioned, but not systematically described in Nakrem \& Mørk (1991), and in Mørk, Elvebakk et al. (1999), has been re-investigated, and some revisions are presented herein (Appendix 1). This includes material from the Vardebukta and Tvillingodden formations of Akseløya, Bjørnskardet and Austjøkeltinden, and material from the Vikinghøgda Formation in Deltadalen.

\section{Previous work}

Since 1975, several papers describing scattered conodont occurrences from the Triassic of Svalbard have been published: Birkenmajer \& Trammer (1975), Trammer (1978), Weitschat \& Lehmann (1978), Clark \& Hatleberg (1983), Hatleberg \& Clark (1984), Dagis \& Korčinskaja (1987, 1989), Nakrem \& Mørk (1991), Mørk, Elvebakk et al. (1999), Luppold (2001) and Nakrem et al. (2001). Since the publication of these data, the taxonomy of Triassic conodonts has in many cases been refined (e.g., Orchard 2007b), and most taxa in the aforementioned publications from Svalbard have now been reassigned to taxa according to modern nomenclature.

Extensive fieldwork and geological study of the Triassic succession of Svalbard have also led to refinement of the lithostratigraphy and biostratigraphy of these units. The Lithostratigraphic lexicon of Svalbard (Dallmann 1999) is the most up-to-date work regarding the lithostratigraphic units discussed in this paper, and includes a biostratigraphic zonation of the Triassic succession compiled by Mørk \& Vigran (1999) and Mørk \& Smelror (1999). Conodont occurrences described in this contribution, coupled with previously established ammonoid zonations, add new knowledge to Boreal correlations, and supplement the lexicon with biostratigraphical data (Fig. 3).

Illustrated specimens (Figs. 4, 5), with Paleontologisk Museum, Oslo (PMO) prefixes, are housed in the collection of type and illustrated palaeontological material of the Natural History Museum, University of Oslo; remaining specimens are housed in the collection of the Geological-Palaeontological Institute and Museum, University of Hamburg. A list of all taxa referred to in this paper is appended for archival purposes (Appendix 2).

\section{Lower Triassic}

\section{Vikinghøgda Formation, Deltadalen Member}

From the Lusitania River, southern side of Sassenfjorden, Dagis \& Korčinskaja (1987) (3 in Fig. 2) reported the presence of two conodont assemblages $6 \mathrm{~m}$ above the base of the formation. The lower assemblage contained Neogondolella carinata and its probable constituent ramiform elements, co-occurring with Otoceras boreale, Glyptophiceras nielseni, Ophiceras (Lytophiceras) spathi, 


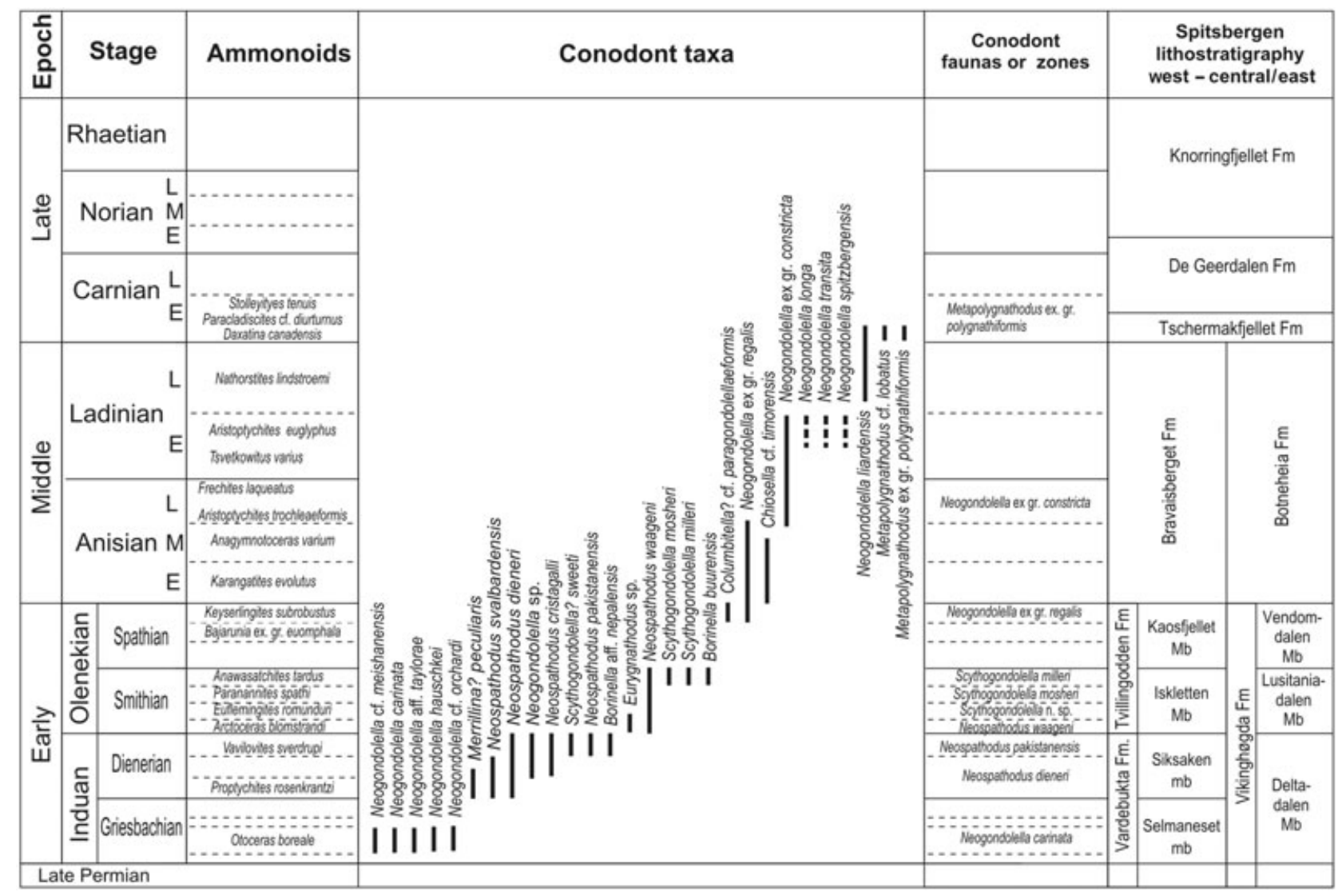

Fig. 3 Range chart of the Triassic conodonts of Spitsbergen. The lithostratigraphy is from Mørk, Dallmann et al. (1999); the ammonoids are from Dagys \& Weitschat (1993). Conodont faunas are mostly informal, and are based partly on Orchard \& Tozer (1997).

Ophiceras (Lytophiceras) sp. cf. compressum, Ophiceras (Lytophiceras) sp. cf. kochi, Ophiceras (Acanthophiceras) sp. cf. poulseni, Paravishnuites paradigma, Paravishnuites oxynotus, Promyalina sp. cf. degeeri, Unionites sp. cf. breviformis and Bellerophon borealis. The conodont species appears in the latest Permian, and occurs throughout the Griesbachian, but its association with the ammonoids indicates an early Griesbachian age for the lower part of the Vikinghøgda Formation (Deltadalen Member) at this locality.

From a higher level in the Deltadalen Member, Dagis \& Korčinskaja (1989) (4 in Fig. 2) reported Neospathodus aff. cristagalli, Neospathodus svalbardensis and Neogondolella sp. occurring with Proptychites species (Proptychites rosenkrantzi, Proptychites simplex, Proptychites cf. candidus and Proptychites cf. strigatus) indicative of the basal Dienerian. This was regarded as equivalent to the fauna reported from the basal Dienerian in the Hornsund region by Birkenmajer \& Trammer (1975), which included Merrillina? peculiaris (formerly Neospathodus), Neospathodus dieneri and the types of Ns. svalbardensis.

From Ahlstrandodden and localities on the eastern shores of Recherchefjorden and Van Keulenfjorden, Dagis
\& Korčinskaja (1989) described Ns. dieneri, Neospathodus pakistanensis, Neospathodus aff. svalbardensis and a new conodont species Neogondolella sweeti. This level may be identical to the Myalina limestone (=Brevassfjellet Beds elsewhere), because Dagis \& Korčinskaja (1987) refer to the conodonts coming from a sample with abundant Promyalina degeeri, as well as Vavilovites spitzbergensis: this implies equivalence with the upper Dienerian sverdrupi Zone of Canada. The conodonts are consistent with this age.

Dagis \& Korčinskaja (1989) included in their new species, $\mathrm{Ng}$. sweeti, a specimen illustrated by Sweet (1970b) that had earlier formed the basis of a second new species, Gondolella sweeti Kozur \& Mostler, 1976. Many Triassic species referred to Gondolella were subsequently moved to Neogondolella, creating a potential nomenclatural conflict. (The genus Neogondolella is used in this paper for some species that others refer to Clarkina. MJO prefers this usage for reasons explained elsewhere; Orchard 2008 [this issue]) However, "G." sweeti is now referred by Kozur to the genus Paragondolella, whereas Orchard (2007b) has referred it to Borinella. The 


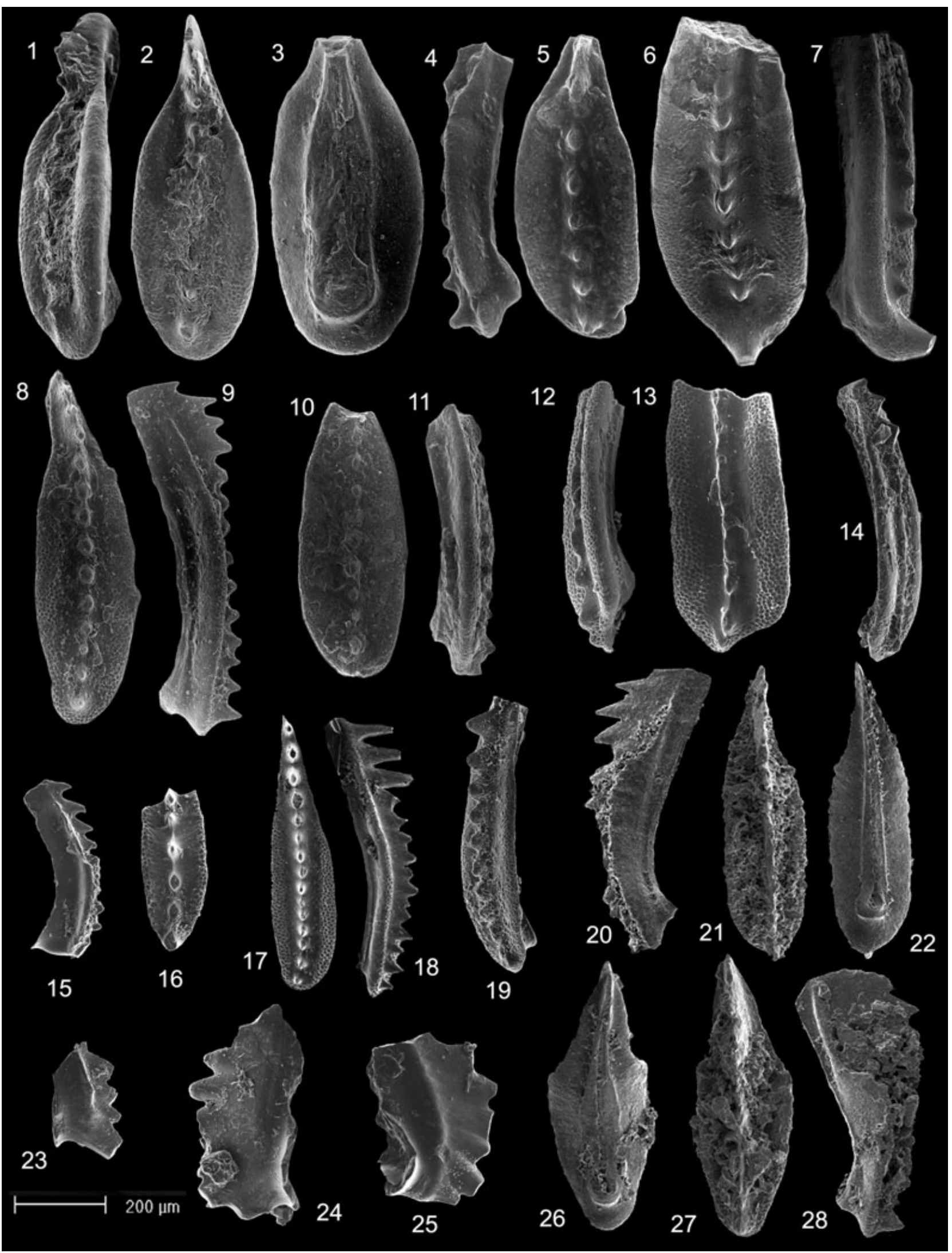


Fig. 4 Illustrated specimens with Paleontologisk Museum, Oslo (PMO) prefix numbers are housed in the collection of type and illustrated palaeontological material of the Natural History Museum, University of Oslo; the remaining specimens are housed in the collection of the Geological-Palaeontological Institute and Museum, University of Hamburg. (4.1-4.3) Neogondolella aff. taylorae Orchard, from Deltadaldalen, Vikinghøgda Formation, Deltadalen Member, $5 \mathrm{~m}$ above base of formation (4.1 and 4.2, PMO 170.990/1; 4.3, PMO 170.990/2.). (4.4 and 4.5) Neogondolella carinata (Clark) from Deltadaldalen, Vikinghøgda Formation, Deltadalen Member, 5 m above base of formation (PMO 170.990/5). (4.6 and 4.7) Neogondolella cf. meishanensis (Zhang, Lai, Ding \& Liu) from Deltadaldalen, Vikinghøgda Formation, Deltadalen Member, 5 m above base of formation (PMO 170.990/4). (4.8 and 4.9) Neogondoella cf. orchardi (Mei), from Deltadaldalen, Vikinghøgda Formation, Deltadalen Member, $11.5 \mathrm{~m}$ above base of formation (PMO 170.993/2). (4.10 and 4.11) Neogondolella hauschkei (Kozur), from Deltadaldalen, Vikinghøgda Formation, Deltadalen Member, $5 \mathrm{~m}$ above base of formation (PMO 170.990/6). (4.12 and 4.13) Neogondolella sp. A, from Mariaholmen, Vardebukta Formation, Siksaken member, Myalina limestone (PMO 170.991/2). (4.14) Neogondolella sp. B, from Austjøkeltinden, Tvillingodden Formation, Skilisen Bed, sample AJT-107 (specimen lost). (4.15 and 4.23) Scythogondolella? sp., from Akseløya, Tvillingodden Formation, Skilisen Bed (4.15, PMO 170.992/5; 4.23, specimen lost). (4.16) Borinella? sp., from Akseløya, Tvillingodden Formation, Skilisen Bed (PMO 170.992/6). (4.17 and 4.18) Borinella aff. buurensis (Dagis), from Sassenfjorden, Vikinghøgda Formation, Lusitaniadalen Member (Type Cat. No. 2166; Weitschat \& Lehmann 1978: pl. 13, fig. 3). (4.19) Borinella buurensis (Dagis), from Austjøkeltinden, Tvillingodden Formation, Skilisen Bed, sample AJT-107 (specimen lost). (4.20-4.22) Columbitella? sp. nov. K of Orchard 2007b, from Milne Edwardsfjellet section MES, Tvillingodden Formation, Vendomdalen Member, sample 311 at $36 \mathrm{~m}$ above base of formation (PMO 170.994/1). (4.24 and 4.25) Neospathodus pakistanensis Sweet, from Akseløya, Tvillingodden Formation, Skilisen Bed (24, PMO 170.992/1; 25, PMO 170.992/2). (4.26-4.28) Columbitella? paragondolellaeformis (Dagis), from Milne Edwardsfjellet section MES, Tvillingodden Formation, Vendomdalen Member, sample 316 at $54.4 \mathrm{~m}$ above base of formation (PMO 170.995/1).

specimens that formed the basis of $\mathrm{Ng}$. sweeti might better be referred to the genus Scythogondolella, although the available illustrations are poor: it is not regarded as the same species as that from Pakistan (Sweet 1970b), although it is in part contemporaneous with that species.

Mørk, Elvebakk et al. (1999) (7 in Fig. 2) reported the presence of $\mathrm{Ng}$. carinata from calcareous nodules 5.0 and $11.5 \mathrm{~m}$ above the base of the Vikinghøgda Formation. Neogondolella cf. meishanensis, Neogondolella hauschkei, Neogondolella cf. orchardi and Neogondolella aff. taylorae are also present in the lower sample (5.0-m sample). These conodonts were found together with $O$. boreale, Claraia stachei, B. borealis and Tompophiceras cf. gracile. Neogondolella meishanensis straddles the Permian-Triassic boundary, whereas the ammonoid association suggests an early Griesbachian age. $\mathrm{Ng}$. aff. taylorae is similar to elements that Kozur (2004) described as Clarkina praetaylorae from the latest Permian of Iran. Both in Iran (Kozur 2005) and in the Canadian Arctic (Beatty et al. 2006), the co-occurrence of $\mathrm{Ng}$. meishanensis and $\mathrm{Ng}$. hauschkei is also considered to be indicative of the latest Changhsingian. Thus, the basal part of the Sassendalen Group may be latest Permian in age, as suggested by palynological (Hochuli et al. 1989), isotope/geochemical (Wignall et al. 1998) and magnetostratigraphic (Hounslow, Peters et al. 2008) data. Higher up in the Deltadalen Member, from a sample $79.0 \mathrm{~m}$ above the base of the member, Neospathodus cf. svalbardensis is identified, and serves as a proxy for the base of the Dienerian.

\section{Vikinghøgda Formation, Lusitaniadalen Member}

A single sample from $2 \mathrm{~m}$ below the top of the Lusitaniadalen Member (MES section, Milne Edwardsfjellet, west, see Hounslow, Hu et al. 2008 [this issue]: fig. 4) yielded specimens of Neospathodus waageni. This species co-occurs here with an ammonoid fauna of Xenoceltites subevolutus, Anawasatchites sp., Arctoprionites nodosus and Anasibirites sp., indicating the late Smithian Wasatchites tardus Zone.

Weitschat \& Lehmann (1978) (9 in Fig. 2) reported the presence of the following species in samples from a level approximately $7 \mathrm{~m}$ below the top of this member, collected from the southern shore of Sassenfjorden, close to Botneheia, from the Anawasatchites tardus Zone: Scythogondolella milleri, Scythogondolella mosheri, Borinella aff. buurensis (originally described as Neogondolella planata, Neogondolella nevadensis and Neogondolella jubata, respectively) and Ns. waageni. The age of this fauna is late Smithian, which correlates with the Scythogondolella milleri Zone of Sweet et al. (1971). The results of a similar reassesment of this fauna by Dagis \& Korčinskaja (1989) concur with this age determination, although they regarded the elements of $\mathrm{Ng}$. jubata as examples of Neogondolella jakutensis, a similar Smithian species from Siberia.

\section{Vikinghøgda Formation, Vendomdalen Member}

Four conodont collections were recovered from the upper part of the Vendomdalen Member at the Milne Edwardsfjellet locality, at 31, 48, 49.1 and $54.4 \mathrm{~m}$ above the base of the Vendomdalen Member (for sample points, see Hounslow, Hu et al. 2008: fig. 4). Each contains gondolellids, some of which resemble the Spathian species Columbitella? sp. nov. K of Orchard (2007b), and, at a higher stratigraphic level, the Siberian species Columbitella? paragondolellaeformis, described from the latest 


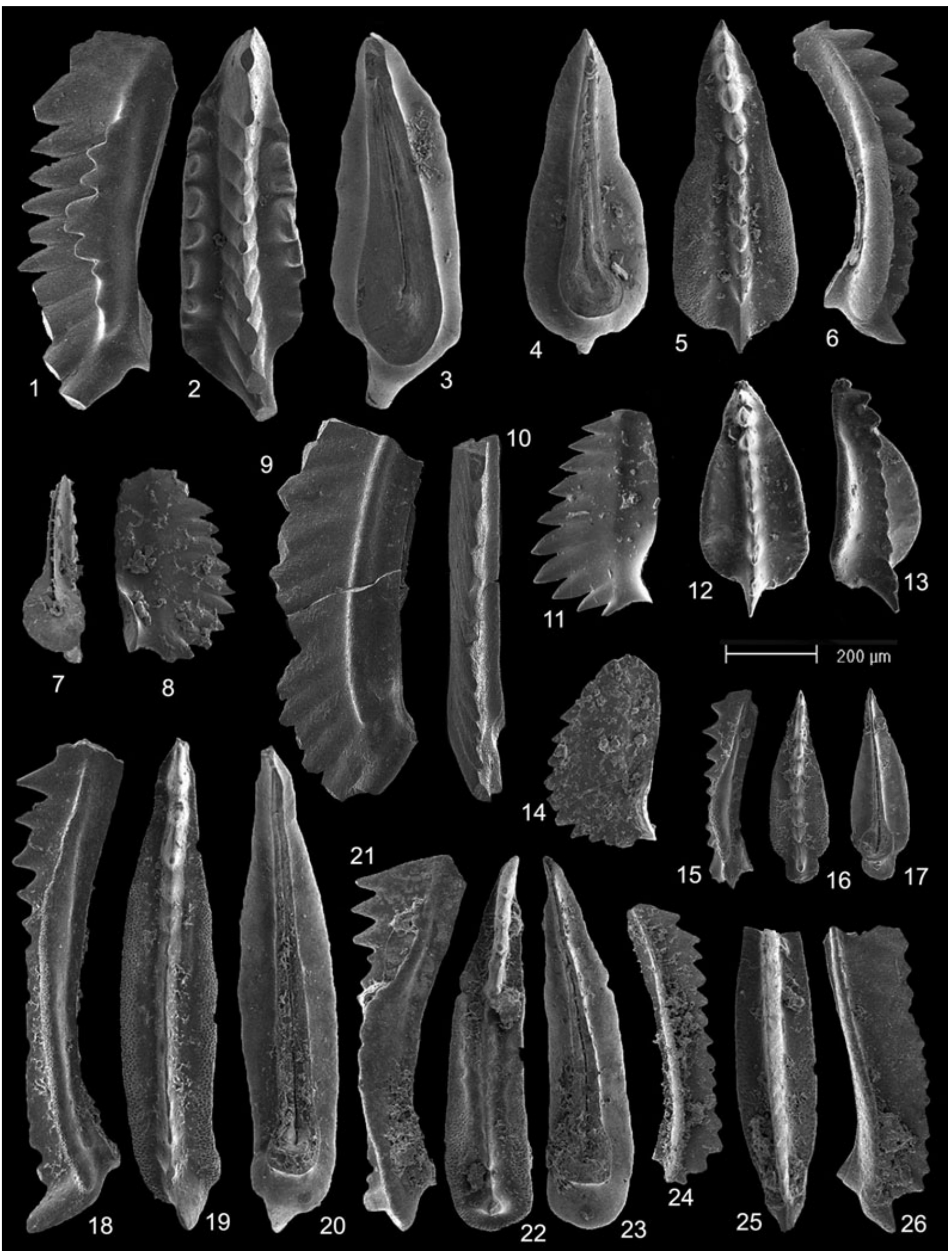


Fig. 5 Illustrated specimens with Paleontologisk Museum, Oslo (PMO) prefix numbers are housed in the collection of type and illustrated palaeontological material of the Natural History Museum, University of Oslo; the remaining specimens are housed in the collection of the GeologicalPalaeontological Institute and Museum, University of Hamburg. (5.1-5.3) Scythogondolella milleri (Müller), from Sassenfjorden, Vikinghøgda Formation, Lusitaniadalen Member (PMO 170.996/1) (5.4-5.6, 5.12 and 5.13) Scythogondolella mosheri (Kozur \& Mostler), Sassenfjorden, Vikinghøgda Formation, Lusitaniadalen Member (5.4-5.6, PMO 170.996/2; 5.12 and 5.13, Type Cat. No. 2172; Weitschat \& Lehmann 1978: pl. 14, figs. 1, 2). (5.7, 5.8 and 5.11) Neospathodus waageni Sweet, from Sassenfjorden, Vikinghøgda Formation, Lusitaniadalen Member (5.7 and 5.8, PMO 170.996/3; 5.11, Type Cat. No. 2182; Weitschat \& Lehmann 1978: pl. 14, fig. 12). (5.14) Neospathodus waageni Sweet, from Milne Edwardsfjellet section MES, Vikinghøgda Formation, Lusitaniadalen Member, sample 301 at $3 \mathrm{~m}$ above base of formation (PMO 170.997/1). (5.9 and 5.10) Chiosella aff. timorensis (Nogami), from Milne Edwardsfjellet section ME, Botneheia Formation, sample 14 at $21.5 \mathrm{~m}$ above base of formation (PMO 170.998/1.). (5.15-5.17) Metapolynathus ex. gr. polygnathiformis (Budurov \& Stefanov), from Milne Edwardsfjellet section MEE, Tschermakfjellet Formation, sample 214 at $1 \mathrm{~m}$ above base of formation (PMO 170.999/1). (5.18-5.20) Neogondolella ex. gr. constricta (Mosher \& Clark), from Milne Edwardsfjellet section ME, Botneheia Formation, sample 78 at $91 \mathrm{~m}$ above base of formation (PMO 171.000/1). (5.21-5.23) Neogondolella liardensis Orchard, from Milne Edwardsfjellet section MEE, Tschermakfjellet Formation, sample 214 at $1 \mathrm{~m}$ above base of formation (PMO 170.999/2). (5.24-5.26) Neogondolella regalis Mosher, from Milne Edwardsfjellet section ME, Botneheia Formation, sample 83 at $96 \mathrm{~m}$ above base of formation, sample 14 at $21.5 \mathrm{~m}$ above base of formation (5.24, PMO 171.001/1; 5.25 and 5.26, PMO 170.998/2).

Olenekian of Siberia (Dagis 1984; Klets 1998). At Milne Edwardsfjellet, these productive levels occur low in the range of the ammonoid Keyserlingites sp., with K. subrobustus at $36 \mathrm{~m}$ above the base of the Vendomdalen Member.

Dagis \& Korčinskaja (1989) reassigned some specimens illustrated by Hatleberg \& Clark (1984; from the Kaosfjellet Member, Sticky Keep Formation) as Ng. jubata. These were associated with the ammonoids of the Keyserlingites subrobustus Zone (K. subrobustus, Svalbardiceras spitzbergense and "Posidonia" aranea). The illustrated conodonts appear to be more closely related to Neogondolella ex. gr. regalis, which appears in the latest Olenekian (Spathian) in the Canadian Arctic.

\section{Vardebukta Formation, Brevassfjellet Bed}

Conodonts have been reported from the basal Triassic beds of the Sørkapp-Hornsund area (the Brevassfjellet Myalina Bed of Birkenmajer 1977; 25-30 m above the base of the Vardebukta Formation) by Birkenmajer $\delta$ Trammer (1975) (1 in Fig. 2), Nakrem \& Mørk (1991) (8 in Fig. 2) and Luppold (2001) (6 in Fig. 2). Conodonts mentioned in Sweet (1970b: 216), Sweet et al. (1971: 451) and Trammer (1978: 283) from Spitsbergen were supplied by G. Hamar, and also from samples from the Brevassfjellet Myalina limestone of this area. An earlymiddle Dienerian age was proposed, and is supported here based on the presence of Ellisonia triassica, Ns. dieneri, Ns. svalbardensis and Merrillina? peculiaris (formerly Neospathodus).

\section{Vardebukta Formation, Siksaken member}

Clark \& Hatleberg (1983) (2 in Fig. 2) and Hatleberg \& Clark (1984) (5 in Fig. 2) reported conodonts from the Siksaken member at Ahlstrandodden, Pitnerodden and
Reinodden (southern side of Van Keulenfjorden), 105$115 \mathrm{~m}$ above the base of the Vardebukta Formation. They recorded (Hatleberg \& Clark 1984: table 2) E. triassica, Ns. dieneri, Neospathodus cristagalli, Ns. svalbardensis, Ns. pakistanensis, Neospathodus peculiaris, Neogondolella elongata, Neogondolella sp. aff. mombergensis, Neogondolella sp. A, Neogondolella sp. B and Neogondolella sp.

A re-study of these collections confirms the presence of the key species Ns. cristagalli, Ns. dieneri, Ns. pakistanensis and Borinella sp., implying a Dienerian age; the reassessment of the elements illustrated by Hatleberg \& Clark (1984) is given in Appendix 1. Early species of both Borinella and ?Scythogondolella may be represented, although the named Neogondolella species are not. At least some records of Ns. svalbardensis may be better interpreted as Ns. pakistanensis, with thickened flanges (i.e., "Neospathodus novaehollandiae"). M.? peculiaris also supports an Induan age. Dagis \& Korčinskaja (1989) concluded that Neogondolella (=Borinella herein) aff. nepalensis was represented in the fauna described by Hatleberg \& Clark (1984), and also identified their new species $\mathrm{Ng}$. sweeti (=Scythogondolella? sweeti, see above). These are all consistent with a late Induan age.

Conodonts were reported from the Myalina limestone of the Siksaken member at Mariaholmen (Bellsund), $125 \mathrm{~m}$ above the base of the Vardebukta Formation, by Nakrem \& Mørk (1991). The conodont fauna from this unit was originally assigned to $\mathrm{Ng}$. elongata, $\mathrm{Ns}$. cf. svalbardensis and E. triassica. Two Neogondolella specimens restudied here lack the attributes of the first taxon, but are insufficiently preserved to assign them to an alternative species.

\section{Tvillingodden Formation, Iskletten Member}

Clark \& Hatleberg (1983) and Hatleberg \& Clark (1984) recovered conodonts from the Iskletten Member at 
Pitnerodden. The conodont Sc. mosheri (Ng. nevadensis, sensu Hatleberg \& Clark 1984) was found in the stratigraphically lowest collection, thereby indicating a Smithian age. Higher in that section, Hatleberg \& Clark (1984: table 2) recorded Neospathodus collinsoni, Neospathodus homeri, Neospathodus cf. triangularis, $\mathrm{Ng}$. elongata and Ng. jubata, which is a typical Spathian association. However, none of these taxa can be verified, and the illustrated specimens appear to be older. The unusual element referred to Ns. collinsoni appears closer to a Eurygnathodus sp., whereas that from the stratigraphically highest sample, referred to $\mathrm{Ng}$. jubata, is close to the Smithian B. buurensis. $\mathrm{Ng}$. elongata is a Spathian species, and the reported occurrences of this species in the Dienerian and Smithian of Svalbard probably represent a species of Borinella. The Neospathodus species from this member are also more readily compared with late Dienerian-early Smithian taxa (Fig. 3). Dagis \& Korčinskaja (1989) came to similar conclusions about the age of the fauna, which they compared with those from the Hedenstroemi Zone of Siberia (Dagis 1984). However, Dagis's revision differed from the present one in regarding the neospathodids as largely representative of Ns. waageni, and the gondolellids as examples of the Siberian Neogondolella aff. composita.

Conodonts were reported from the Skilisen Bed of the Iskletten Member at Akseløya, Bjørnskardet and Austjøkeltinden $(4,20$ and $2 \mathrm{~m}$ above the base of the bed, respectively) by Nakrem \& Mørk (1991). The conodont fauna from this unit was originally assigned to $\mathrm{Ng}$. elongata, Ns. cf. svalbardensis and E. triassica. Restudied elements from Akseløya are revised here as Borinella? sp., Neogondolella sp. B, Ns. pakistanensis and Scythogondolella? sp. Gondolellid elements from Austjøkeltinden appear to correspond to B. buurensis.

\section{Tvillingodden Formation, Kaosfjellet Member}

Clark \& Hatleberg (1983) and Hatleberg \& Clark (1984) recovered conodonts from the Kaosfjellet Member at Reinodden. The significant taxa recorded by those authors were Neogondolella mombergensis and $\mathrm{Ng}$. nevadensis. The latter species was also recorded from the Iskletten Member, but illustrations of those specimens (from the Iskletten Member) clearly identify a Smithian age. However, the only elements illustrated from the present member were assigned to $\mathrm{Ng}$. mombergensis, a species typical of the Middle Triassic. Dagis \& Korčinskaja (1989) reinterpreted the taxa as $\mathrm{Ng}$. jubata, a typical Spathian species, into which various forms have been submerged. In this work, the species is assigned to $\mathrm{Ng}$. ex. gr. regalis, an equally broad concept that is known to range from the late Spathian through the middle Anisian. The presence of K. subrobustus and "P." aranea in this member indicates a probable latest Spathian age for the unit (Tozer 1994).

\section{Middle Triassic}

\section{Botneheia Formation}

Conodonts extracted from the lower Botneheia Formation at the Milne Edwardsfjellet locality include $\mathrm{Ng}$. ex. gr. regalis and a single specimen of Chiosella cf. timorensis, which imply an early-middle Anisian age, based on new data from China and Japan.

Neogondolella ex. gr. constricta from the middle part of the formation implies a late Anisian-early Ladinian age.

From the top $0.2 \mathrm{~m}$ of the Botneheia Formation the conodont Neogondolella liardensis implies a position close to the Ladinian-Carnian boundary (Orchard 2007a).

From the Botneheia Formation of Sassenfjorden (Botneheia), Dagis \& Korčinskaja (1989) reported and illustrated the species Neogondolella longa, Neogondolella transita and Neogondolella spitzbergensis, for which they conclude an early Ladinian age. The rather poor illustrations of these conodonts do not lend themselves to confident reassignment, particularly because of the lack of crucial views. However, amongst them appear examples of $\mathrm{Ng}$. ex. gr. regalis and, probably, $\mathrm{Ng}$. ex. gr. constricta, which together argue for an Anisian age. The co-occurrence of the ammonoids Aristoptychites cf. euglyphus and Indigirophyllites spetsbergensis points to an earliest Ladinian age.

\section{Bravaisberget Formation}

Clark \& Hatleberg (1983) and Hatleberg \& Clark (1984) published conodonts from the basal beds of the Botneheia Formation (now the Passhatten Member of the Bravaisberget Formation) at Reinodden, and from a single sample at Pitnerodden. At the first locality, the species Neogondolella regale $=\mathrm{Ng}$. ex. gr. regalis was recorded, and a single specimen was illustrated. Such elements might also be expected in the late Spathian, although they are far more common in the early-middle Anisian. The single specimen of $\mathrm{Ng}$. elongata recorded from Pitnerodden suggests an older age, but it was only illustrated in lateral view, and cannot be identified.

Conodonts interpreted to be Ladinian in age were also reported by Trammer (1978) from samples collected at Treskelen, within the Somovbreen Member of the Bravaisberget Formation (Drevbreen Formation of Birkenmajer 1977 and Trammer 1978). These comprise Ng. mombergensis subspp. and Neogondolella haslachensis trammeri. As with other Spitsbergen material, the published illustrations are rather poor, but they appear to 
represent various growth stages of one or two species for which the given names are regarded as inappropriate here. They could be as old as Anisian, but re-examination is necessary to be sure.

\section{Upper Triassic}

\section{Tschermakfjellet Formation}

Conodonts reported by Hounslow et al. (2007) (11 in Fig. 2) from the lowermost part of the Tschermakfjellet Formation at Milne Edwardsfjellet include a Carnian fauna comprising $\mathrm{Ng}$. liardensis, Metapolygnathus ex. gr. polygnathiformis and Metapolygnathus cf. lobatus. The first and last of these taxa were recently described by Orchard (2007a) from the Ladinian-Carnian boundary beds in western Canada.

\section{Triassic conodont biostratigraphy and Boreal correlation}

\section{Correlation with the Canadian Arctic (the Sverdrup Basin)}

Conodont faunas from the Sverdrup Basin of the Canadian Arctic are relatively poorly known, but the systematic descriptions of Lower Triassic faunas have been provided by Orchard (2007b), and elsewhere in this issue (Orchard 2008). Further data, particularly from the Permian-Triassic interval and the basal Triassic, have been presented by Henderson (1993), Henderson \& Baud (1997) and Beatty et al. (2006).

The lowermost conodont fauna in the Triassic of Svalbard, from the Vikinghøgda Formation, is associated with the ammonoid Otoceras boreale, and contains rare $\mathrm{Ng}$. cf. meishanensis, $\mathrm{Ng}$. aff. taylorae and $\mathrm{Ng}$. hauschkei, and the more common $\mathrm{Ng}$. carinata. This fauna is correlative with assemblage $\mathrm{C}$ or D of Henderson $\&$ Baud (1997) from the lower part of the Blind Fiord Formation, Otto Fiord section, Ellesmere Island. Their assemblage D also contains Hindeodus parvus, which is the index for the base of the Triassic, but, as they state, "in the Canadian Arctic, H. parvus is exceptionally rare" (Henderson \& Baud 1997: 150). These authors also recorded $\mathrm{Ng}$. taylorae from their assemblage D, a species that was introduced by Orchard et al. (1994), based on faunas from the Otoceras beds of Selong, and that formed the basis of the basal Triassic taylorae Zone in Spiti (Orchard, in Krystyn \& Orchard 1996; see also Jiang et al. 2007), and was later subsumed in the meishanensis Zone of Orchard \& Krystyn (1998). Henderson $\delta$ Baud (1997) also point out the biostratigraphic impor- tance of this species for the recognition of the PermianTriassic boundary, as gondolellids are richer in both species, and specimens in the deeper and colder water deposits of the Boreal and Notal areas, as compared with the type area in China. Beatty et al. (2006) also reported the presence of rare $\mathrm{Ng}$. meishanensis and $\mathrm{Ng}$. hauschkei, and the more common $\mathrm{Ng}$. carinata, together with $O$. boreale, in the lower part of several sections of the Blind Fiord Formation, although in each of these cases, where $H$. parvus was present it succeeded this assemblage.

The latest Griesbachian strigatus Zone of the Arctic contains $\mathrm{Ng}$. carinata, M.? peculiaris, Ns. cristagalli and Ns. dieneri (Orchard 2008), all of which are also known in Svalbard in the lower parts of both the Vikinghøgda and Vardebukta formations. (Species reported in Orchard [2008] from the Canadian Arctic but not found in the Triassic of Svalbard are not considered in the following discussion.) In particular, Ns. dieneri ranges up through the Dienerian, and is especially common in the candidus Zone on Ellesmere Island. The same species is common on Svalbard, but the fauna from the late Dienerian Vavilovites sverdrupi Zone of the Deltadalen Member is more diverse, and includes elements that are only known from the younger romunduri Zone in Canada (e.g., Ns. pakistanensis). Ns. svalbardensis has a Dienerian range in both Arctic Canada and Svalbard, and is also known from the Dienerian Havert Formation of the Barents Shelf (Nakrem et al. 2001).

Conodonts of the late Smithian Wasatchites tardus Zone have several species in common in both Arctic Canada and Svalbard: notably Sc. milleri, Sc. mosheri, Ns. waageni and $B$. buurensis. These species also have ranges outside the Boreal basin, and provide good biostratigraphic correlations elsewhere (Orchard 2008).

The Spathian successions in both Svalbard and in Arctic Canada are sparse in terms of both conodonts and ammonoids. No Spathian conodonts older than the Keyserlingites subrobustus Zone are known from Canada or from the Svalbard succession. This ammonoid zone is recorded from both the Vendomdalen and Kaosfjellet members, where it contains elements of $\mathrm{Ng}$. ex. gr. regalis, as it does in Canada (Orchard 2008). A second group of gondolellids tentatively referred to Columbitella? spp. occur in the Vendomdalen Member, and may be a little older. Lower-middle Spathian elements reported from the Iskletten Member by Hatleberg \& Clark (1984) are re-interpreted herein as Smithian.

Middle Triassic conodonts from the Canadian Arctic are known from the Murray Harbour Formation on Ellesmere Island, but they have yet to be studied in detail. Comparisons may nevertheless be made with the faunas of the Botneheia and Bravaisberget formations of 
Svalbard, through the common occurrences of both $\mathrm{Ng}$. ex. gr. regalis and $\mathrm{Ng}$. ex. gr. constricta. All of these collections are dominated by Neogondolella species, some of which are almost certainly new. Unlike in Svalbard, Chiosella has not been found in the Canadian Arctic.

Conodonts are known from around the Middle-Upper Triassic (Ladinian-Carnian) boundary in both the Hoyle Bay Formation in Canada and the Tschermakfjellet Formation in Svalbard. In common with the Tschermakfjellet Formation collections, the Canadian collections contain early metapolygnathids, in addition to ubiquitous Neogondolella species, implying a Carnian age. The youngest Late Triassic conodonts in the Canadian Arctic are those associated with late Carnian welleri Zone ammonoids in the Blaa Mountain Formation of Axel Heiberg Island. This site produced the type specimens of Metapolygnathus reversus (Mosher 1973). Conodonts of this age or younger (Norian and Rhaetian) are still to be found within the Upper Triassic of Svalbard.

\section{Acknowledgements}

We thank Charles Henderson (Calgary) and Jan A. Rasmussen (Copenhagen) for their helpful reviews.

\section{References}

Beatty T.W., Henderson C.M., Orchard M.J. \& Beauchamp B. 2006. Early Triassic (Induan) conodont biostratigraphy of the Sverdrup Basin, Canadian Arctic. In H.A. Nakrem \& A. Mørk (eds.): Boreal Triassic 2006. Longyerbyen, Svalbard, 16-19 August 2006. NGF Abstracts and Proceedings of the Geological Society of Norway 3, 41.

Bender H. 1970. Zur Gliederung der mediterranen Trias II. Die Conodontenchronologie der mediterranen Trias. (On the subdivision of the Mediterranean Triassic II. Conodont chronology of the Mediterranean Triassic.) Extract Annales Géologiques des Pays Helléniques 19, 465-540.

Birkenmajer K. 1977. Triassic sedimentary formations of the Hornsund area, Spitsbergen. Studia Geologica Polonica 51, 7-74.

Birkenmajer K. \& Trammer J. 1975. Lower Triassic conodonts from Hornsund, south Spitsbergen. Acta Geologica Polonica 25, 299-307.

Bittner A. 1901. Lamellibranchiaten aus der Trias des Bakonyer Waldes. (Lamellibranchia from the Triassic of the Bakony.) Resultate der wissenschaftlichen Erforschung des Balatonsees. 1(1). Budapest: Ungarische Geografische Gesellschaft.

Buchan S.H., Challinor A., Harland W.B. \& Parker J.R. 1965. The Triassic stratigraphy of Svalbard. Norsk Polarinstitutt Skrifter 135. Oslo: Norwegian Polar Institute.

Budurov K. \& Stefanov S. 1965. Gattung Gondolella aus der Trias Bulgariens. (The genus Gondolella from the Triassic of Bulgaria.) Doklady Bolgarskoy Akademiya Nauk, Série Paléontologie 7, 115-127.
Clark D.L. 1959. Conodonts from the Triassic of Nevada and Utah. Journal of Paleontology 33, 305-312.

Clark D.L. \& Hatleberg E.W. 1983. Paleoenvironmental factors and the distribution of conodonts in the Lower Triassic of Svalbard and Nepal. Fossils and Strata 15, $171-175$.

Dagis A.A. 1984. Rannetriasovye konodonty severa Srednej Sibiri. (Early Triassic conodonts of northern Middle Siberia.) Trudy Akademija SSSR, Sibirskoe otdelenie Instituta Geologii i Geofiziki 554, 3-69.

Dagis A.A. \& Korčinskaja M.V. 1987. Pervye nahodki konodontov v otocerasovyh slojah Sval'barda. (The first discoveries of conodonts in the Otoceras beds of Svalbard.) Trudy Akademija SSSR, Sibirskoe otdelenie Instituta Geologii i Geofiziki 689, 110-113.

Dagis A.A. \& Korčinskaja M.V. 1989. Triasovye konodonty Sval'barda. (Triassic conodonts of Svalbard.) In A.S. Dagis \& V.N. Dubatolov (eds.): Verhnij Paleozoj i Trias Sibiri. (Upper Paleozoic and Triassic of Siberia.) Trudy Akademija Nauk SSSR, Sibirskoe otdelenie Instituta Geologii i Geofiziki 732, 109-121.

Dagys A.S. \& Weitschat W. 1993. Correlation of the Boreal Triassic. Mitteilungen Geologisch-Paläontologisches Institut Universität Hamburg 75, 249-256.

Dallmann W.K. (ed.) 1999. Lithostratigraphic lexicon of Svalbard. Upper Palaeozoic to Quaternary bedrock. Review and recommendations for nomenclature use. Tromsø: Norwegian Polar Institute.

Egorov A.Y. \& Mørk A. 2000. The East Siberian and Svalbard Triassic successions and their sequence stratigraphical relationships. Zentralblatt für Geologie und Paläontologie Teil 1, 1377-1430.

Frebold H. 1929a. Faunistisch-stratigraphische Untersuchungen über die Trias Spitsbergens und der Edge-Insel. (Faunistic and stratigraphic research on the Triassic of Spitsbergen and Edgeøya.) Abhandlungen des Naturwissenschaftlichen Vereins zu Hamburg 22, 293-312.

Frebold H. 1929b. Untersuchungen über die Fauna, die Stratigraphie und Paläogeographie der Trias Spitzbergens. (Studies of the fauna, stratigraphy and palaeogeography of the Triassic of Spitsbergen.) Skrifter om Svalbard og Ishavet 26. Oslo: Norway's Svalbard and Arctic Ocean Research Survey.

Frebold H. 1930. Die Altersstellung des Fischhorizontes, des Grippeaniveaus und des unteren Saurierhorizontes in Spitzbergen. (The age of the fish horizon, the Grippea levels and the lower Saurian horizon in Spitsbergen.) Skrifter om Svalbard og Ishavet 28. Oslo: Norway's Svalbard and Arctic Ocean Research Survey.

Hatleberg E.W. \& Clark D.L. 1984. Lower Triassic conodonts and biofacies interpretations: Nepal and Svalbard. Geologica et Palaeontologica 18, 101-125.

Henderson C.M. 1993. Are Permian-Triassic boundary events diachronous? Evidence from the Canadian Arctic. In: Carboniferous to Jurassic Pangea. Annual Convention, Canadian Society of Petroleum Geologists, Calgary, Canada. Program and abstracts. P. 136. Calgary: Canadian Society of Petroleum Geology. 
Henderson C.M. \& Baud A. 1997. Correlation of the Permian-Triassic boundary in Arctic Canada and comparison with Meishan, China. In N.W. Wang \& J. Remane (eds.): Stratigraphy. Proceedings of the 30th International Geological Congress 11. Pp. 143-152. Utrecht: VSP.

Hochuli P.A., Colin J.P. \& Vigran J.O. 1989. Triassic biostratigraphy of the Barents Sea area. In J.D. Colinson (ed.): Correlation in hydrocarbon exploration. Pp. 131-153. London: Graham \& Trotman.

Hoel A. \& Orvin A.K. 1937. Das Festungsprofil auf Spitzbergen Karbon-Kreide. I: Vermessungsresultate. (The Festningen section on Spitsbergen. Carboniferous-Cretaceous. I: measuring results.) Skrifter om Svalbard og Ishavet 18. Oslo: Norway's Svalbard and Acrtic Ocean Research Survey.

Hounslow M.W., Hu M., Mørk A., Vigran J., Weitschat W. \& Orchard M.J. 2007. Magneto-biostratigraphy of the Middle to Upper Triassic transition, central Spitsbergen, Arctic Norway. Journal of the Geological Society, London 164, 581-597.

Hounslow M.W, Hu M., Mørk A., Weitschat W., Vigran J.O., Karloukovski V. \& Orchard M.J. 2008. Intercalibration of Boreal and Tethyan time scales: the magnetobiostratigraphy of the Middle Triassic and the latest Early Triassic from Spitsbergen, Arctic Norway. Polar Research 27, 469-490.

Hounslow M.W., Peters C., Mørk A., Weitschat W. \& Vigran J.O. 2008. Bio-magnetostratigraphy of the Vikinghøgda Formation, Svalbard (Arctic Norway) and the geomagnetic polarity timescale for the Lower Triassic. Geological Society of America Bulletin.

Huckriede R. 1958. Die Conodonten der mediterranen Trias und ihr stratigraphischer Wert. (Triassic conodonts from the Mediterranen Triassic and their stratigraphic value.) Paläontologische Zeitschrift 32, 141-175.

Jiang H., Lai X., Luo G., Aldridge R.J., Zhang K. \& Wignall P. 2007. Restudy of conodont zonation and evolution across the P/T boundary at Meishan section, Changxing, Zhejiang, China. Global and Planetary Change 55, 39-55.

Klets T.V. 1998. Novye vidy konodontov iz Nižnego Triasa Kolymskogo Bassejna. (New species of conodonts from the Lower Triassic of the Kolyma River Basin.) News of Paleontology and Stratigraphy 1. Supplement to Geologija i Geofizika 39, 113-122.

Korčinskaja M.V. 1982. Ob"'jasnitel'naja zapiska $k$ stratigrafičeskoj sheme mezozoja (trias) Sval'barda. (An explanatory note to the stratigraphic scheme of the Mesozoic [Triassic] of Svalbard.) Leningrad: Production-Geological Association Sevmorgeologija.

Korčinskaja M.V. 1986. Biostratigrafija indskogo jarusa Špicbergena. (Biostratigraphy of the Induan stage of Spitsbergen.) In: Geologija osadočnogo čehla Špicbergena. (Geology of the sedimentary cover of the Spitsbergen archipelago.) Pp. 77-93. Leningrad: Production-Geological Association Sevmorgeologija.

Kozur H. 2004. Pelagic uppermost Permian and the Permian-Triassic boundary conodonts of Iran. Part 1:
Taxonomy. Hallesches Jahrbuch for GeoWissenshaften. Reihe B, Beiheft 18, 29-68.

Kozur H. 2005. Biostratigraphy and event stratigraphy in Iran around the Permian-Triassic Boundary (PTB): implications for the causes of the PTB biotic crisis. Global and Planetary Change 55, 155-176.

Kozur H. \& Mock R. 1972. Neue Conodonten aus der Trias der Slowakei und ihre stratigraphische Bedeutung. (New conodonts from the Triassic of Slovakia and their stratigraphic significance.) Geologisch-Paläontologische Mitteilungen Innsbruck 2, 1-20.

Kozur H. \& Mostler H. 1971. Probleme der Conodontenforschung in der Trias. (Problems concerning the study of Triassic conodonts.) Geologisch-Paläontologische Mitteilungen Innsbruck 1, 1-19.

Kozur H. \& Mostler H. 1976. Neue Conodonten aus dem Jungpaläozoikum und der Trias. (New Late Palaeozoic and Triassic conodonts.) Geologisch-Paläontologische Mitteilungen Innsbruck 6, 1-40.

Kozur H. \& Pjatakova M. 1976. Die Conodontenart Anichignathodus parvus n.sp., eine wichtige Leitform der basalen Trias. (The conodont species Anichignathodus parvus n.sp., an important index fossil in the basal Triassic.) Koninklijke Nederlandse Akademie van Wetenschappen, Proceedings, Series B, 79, 123-128.

Krajewski K.P., Karcz P., Wozny E. \& Mørk A. 2007. Type section of the Bravaisberget Formation (Middle Triassic) at Bravaisberget, western Nathorst Land, Spitsbergen, Svalbard. Polish Polar Research 28, 79-122.

Krystyn L. \& Orchard M.J. 1996. Lowermost Triassic ammonoid and conodont biostratigraphy of Spiti, India. Albertiana 17, 10-21.

Lindström G. 1865. Om Trias-och Juraförsteningar från Spetsbergen. (On Triassic and Jurassic fossils from Spitsbergen.) Kungliga Svenska Vetenskapsakademiens Handlingar 6, 1-20. Uppsala: Swedish Royal Academy of Sciences.

Lock B.E., Pickton C.A.G., Smith D.G., Batten D.J. \& Harland W.B. 1978. The geology of Edgeøya and Barentsøya, Svalbard. In: Norsk Polarinstitutt Skrifter 168. Pp. 7-64. Oslo: Norwegian Polar Institute.

Lundgren B. 1887. Anmärkningar om Permfossil från Spetsbergen. (Remarks on Permian fossils from Spitsbergen.) Kungliga Svenska Vetenskapsakademiens Handlingar 13. Uppsala: Swedish Royal Academy of Sciences.

Luppold F.W. 2001. New biostratigraphic data from west Spitsbergen based on conodonts. Geologisches Jahrbuch B 91, 603-633.

McLearn F.H. 1945. The Lower Triassic of Liard River, British Columbia. Canada Geology Survey Paper 45-28. Ottowa: Geological Survey of Canada.

Mei S. 1996. Restudy of conodonts from the PermianTriassic boundary beds at Selong and Meishan and the natural Permian-Triassic boundary. In H. Wang $\delta$ X. Wang (eds.): Centennial memorial volume of Professor Sun Yunzhu (Sun Y.C.). Stratigraphy and palaeontology. Pp. 141-148. Wuhan: China University of Geosciences Press. 
Mojsisovics E. 1886. Arktische Triasfaunen. Beiträge zur paläontologischen Charakteristik der Arktisch-Pacifischen Triasprovinz. (Arctic Triassic faunas. Contributions to the palaeontological characteristics of the Arctic-Pacific Triassic [faunal] province.) Mémoires de l'Académie Impériale des Sciences de St. Pétersbourg, Séries 7 33(6). St. Petersburg: Imperial Academy of Sciences.

Mørk A. \& Bjorøy M. 1984. Mesozoic source rocks on Svalbard. In A.M. Spencer et al. (eds.): Petroleum geology of the North European margin. Pp. 371-382. London: Graham $\&$ Trotman.

Mørk A., Dallmann W.K, Dypvik H., Johannessen E.P., Larssen G.B., Nagy J., Nøttvedt A., Olaussen S., Pchelina T.M. \& Worsley D. 1999. Mesozoic lithostratigraphy. In W.K. Dallmann (ed.): Lithostratigraphic lexicon of Svalbard. Upper Palaeozoic to Quaternary bedrock. Review and recommendations for nomenclature use. Pp. 127-214. Tromsø: Norwegian Polar Institute.

Mørk A., Elvebakk G., Forsberg A.W., Hounslow M.W., Nakrem H.A., Vigran J.O. \& Weitschat W. 1999. The type section of Vikinghøgda Formation: a new Lower Triassic unit in central and eastern Svalbard. Polar Research 18, 51-82.

Mørk A., Knarud R. \& Worsley D. 1982. Depositional and diagenetic environments of the Triassic and Lower Jurassic succession of Svalbard. In A.F. Embry \& H.R. Balkwill (eds.): Arctic geology and geophysics: proceedings of the Third International Symposium on Arctic Geology. Pp. 371-398. Calgary: Canadian Society of Petroleum Geologists.

Mørk A. \& Smelror, M. 1999. Biozones of the Kapp Toscana Group. In W.K. Dallmann (ed.): Lithostratigraphic lexicon of Svalbard. Upper Palaeozoic to Quaternary bedrock. Review and recommendations for nomenclature use. P. 312. Tromsø: Norwegian Polar Institute.

Mørk A. \& Vigran J.O. 1999. Biozones of the Sassendalen Group. In W.K. Dallmann (ed.): Lithostratigraphic lexicon of Svalbard. Upper Palaeozoic to Quaternary bedrock. Review and recommendations for nomenclature use. P. 311. Tromsø: Norwegian Polar Institute.

Mørk A., Vigran J.O., Korchinskaya M.V., Pchelina T.M., Fefilova L.A., Vavilov M.N. \& Weitschat W. 1992. Triassic rocks in Svalbard, the Arctic Soviet islands and the Barents Shelf: bearing on their correlations. In T.O. Vorren et al. (eds.): Arctic geology and petroleum potential: proceedings of the Norwegian Petroleum Society Conference, 15-17 August 1990, Tromsø, Norway. Pp. 457-479. Amsterdam: Elsevier.

Mosher L.C. 1970. New conodont species as Triassic guide fossils. Journal of Paleontology 44, 737-742.

Mosher L.C. 1973. Triassic conodonts from British Colombia and the northern Arctic Island. Geological Survey of Canada Bulletin 222, 141-192.

Mosher L.C. \& Clark D.L. 1965. Middle Triassic conodonts from the Prida Formation of northwestern Nevada. Journal of Paleontology 39, 551-565.

Müller K.J. 1956. Triassic conodonts from Nevada. Journal of Paleontology 30, 818-830.
Nakrem H.A. \& Mørk A. 1991. New early Triassic bryozoa (Trepostomata) from Spitsbergen, with some remarks on the stratigraphy of the investigated horizons. Geological Magazine 128, 129-140.

Nakrem H.A., Szaniawski H. \& Mørk A. 2001. PermianTriassic scolecodonts and conodonts from the Svalis Dome, central Barents Sea, Norway. Acta Palaeontologica Polonica 46, 67-84.

Nogami Y. 1968. Trias-Conodonten von Timor, Malaysia und Japan. (The Triassic conodonts of Timor, Malaysia and Japan.) Memoirs of Faculty of Sciences, Kyoto University (Geology and Mineralogy) 34, 115-136.

Öberg P. 1877. Om trias-försteningar från Spetsbergen. (On Triassic fossils from Spitsbergen.) Kungliga Svenska Vetenskapsakademiens Handlingar 14. Uppsala: Swedish Royal Academy of Sciences.

Orchard M.J. 1994. Conodont biochronology around the Early-Middle Triassic boundary: new data from North America, Oman and Timor. In J. Geux \& A. Baud (eds.): Recent developments on Triassic stratigraphy: proceedings of the Triassic Symposium, Lausanne, 1991. Pp. 105-114. Lausanne: Institute of Geology and Paleontology, University of Lausanne.

Orchard M.J. 2007a. New conodonts and zonation, Ladinian-Carnian boundary beds, British Columbia, Canada. New Mexico Museum of Natural History and Science Bulletin 41, 321-330.

Orchard M.J. 2007b. Conodont diversity and evolution through the latest Permian and Early Triassic upheavals. Palaeogeography, Palaeoclimatology, Palaeoecology 252, 93-117. Orchard M.J. 2008. Lower Triassic conodonts from the Canadian Arctic, their intercalibration with ammonoid-based stages and a comparison with other North American Olenekian faunas. Polar Research 27, 393-412.

Orchard M.J. \& Krystyn L. 1998. Conodonts of the lowermost Triassic of Spiti, and new zonation based on Neogondolella successions. Revista Italiana di Paleontologia Stratigraphia 104, 341-368.

Orchard M.J., Nassichuk W.W. \& Rui L. 1994. Conodonts from the Lower Griesbachian Otoceras latilobatum bed of Selong, Tibet and the position of the P-T boundary. In A.F. Embry et al. (eds.): Pangea: global environments and resources. Pp. 823-843. Calgary: Canadian Society of Petroleum Geologists.

Orchard M.J. \& Tozer E.T. 1997. Triassic conodont biochronology, its calibration with the ammonoid standard, and a biostratigraphic summary for the Western Canada Sedimentary Basin. In T. Moslow \& J. Wittenberg (eds.): Triassic of Western Canada Basin. Bulletin of Canadian Petroleum Geology 45, 675-692.

Riis F., Lunschien T., Høy T., Mørk A. \& Mørk M.B. 2008. Evolution of the Triassic shelf in the northern Barents Sea region. Polar Research 27, 318-338.

Solien M.A. 1979. Conodont biostratigraphy of the Lower Triassic Thaynes Formation, Utah. Journal of Paleontology 53, 276-306. 
Spath L.F. 1930. The Eo-Triassic invertebrate fauna of East Greenland. Meddelelser om Grønland 83. Copenhagen: Commission for Scientific Research in Greenland.

Spath L.F. 1934. Catalogue of the fossil Cephalopoda. London: British Museum Publications.

Spath L.F. 1935. Additions to the Eo-Triassic invertebrate fauna of East Greenland. Meddelelser om Grønland 98. Copenhagen: Commission for Scientific Research in Greenland.

Sweet W.C. 1970a. Permian and Triassic conodonts from a section at Guryul Ravine, Vihi District, Kashmir. University of Kansas Paleontological Contributions 49. Lawrence, KS:

Paleontological Institute, University of Kansas.

Sweet W.C. 1970b. Uppermost Permian and Lower Triassic conodonts of the Salt Range and Trans-Indus Ranges, West Pakistan. In B. Kummel \& C. Teichert (eds.): Stratigraphic boundary problems: Permian and Triassic of west Pakistan. Pp. 207-275. Lawrence, KS: University of Kansas Press.

Sweet W.C., Mosher L.C., Clark D.L., Collinson J.W. \& Hasenmueller W.A. 1971. Conodont biostratigraphy of the Triassic. In W.C. Sweet \& S.M. Bergström (eds.): Symposium on Conodont Biostratigraphy. Geological Society of America Memoir 127. Pp. 441-465. Boulder: Geological Society of America.

Tatge U. 1956. Conodonten aus dem germanischen Muschelkalk. (Conodonts from the Germanic Muschelkalk.) Paläontologische Zeitschrift 30, 108-127.

Tozer E.T. 1961. Triassic stratigraphy and faunas, Queen Elizabeth Islands, Arctic archipelago. Geological Survey of Canada Memoir 316. Ottawa: Geological Survey of Canada.

Tozer E.T. 1994. Canadian Triassic ammonoid faunas. Geological Survey of Canada Bulletin 467. Ottawa: Geological Survey of Canada.
Tozer E.T. \& Parker J.R. 1968. Notes on the Triassic biostratigraphyof Svalbard. Geological Magazine 105, 526-542.

Trammer J. 1978. Middle Triassic (Ladinian) conodonts and cephalopod arm hooks from Hornsund, Spitsbergen. Acta Geologica Polonica 28, 283-287.

Trümpy R. 1969. Notes on Triassic stratigraphy and paleontology of north-eastern Jameson Land (East Greenland). II. Lower Triassic ammonites from Jameson Land (East Greenland). Meddelelser om Grønland 168, 77-116.

Weitschat W. \& Dagys A.S. 1989. Triassic biostratigraphy of Svalbard and a comparison with NE-Siberia. Mitteilungen Geologisch-Paläontologisches Institut Universität Hamburg 68, 179-213.

Weitschat W. \& Lehmann U. 1978. Biostratigraphy of the uppermost part of the Smithian Stage (Lower Triassic) at the Botneheia, W-Spitsbergen. Mitteilungen GeologischPaläontologischen Institut Universität Hamburg 48, 85-100.

Wignall P.B., Morante R. \& Newton R. 1998. The Permo-Triassic transition in Spitsbergen: $\delta^{13} \mathrm{C}_{\text {org }}$ chemostratigraphy, Fe and S geochemistry, facies, fauna and trace fossils. Geological Magazine 135, 47-62.

Worsley D. 2008. The post-Caledonian development of Svalbard and the western Barents Sea. Polar Research 27, 298-317.

Zhang K., Lai X., Ding M. \& Liu J. 1995. Conodont sequence and its global correlation of Permian-Triassic boundary in Meishan section, Changxing, Zhejiang Province. Earth Science, Journal of China University of Geosciences 20, 669-676. 


\section{Appendix 1}

Taxonomic reassessments of previously published conodonts from Svalbard are shown in the table below.

Hatleberg \& Clark (1984)

Vardebukta Formation, Siksaken member

Ahlstrandodden section

$\begin{array}{lll}\text { PI. 1, Fig. } 6 & \text { Ah-1-79 } & \text { Neospathodus dieneri } \\ \text { PI. 2, Fig. } 9 & \text { Ah-1-79 } & \text { Ellisonia triassica } \\ \text { PI. 2, Fig. } 10 & \text { Ah-1-79 } & \text { Neospathodus peculiaris } \\ \text { PI. 1, Fig. 3 } & \text { Ah-7-79 } & \text { Neogondolella sp. B } \\ \text { Pitnerodden section } & & \\ \text { PI. 1, Fig. } 7 & \text { Pt-1-79 } & \text { Neogondolella elongata } \\ \text { PI. 1, Fig. } 17 & \text { Pt-1-79 } & \text { Neospathodus svalbardensis } \\ \text { PI. 2, Figs. 2, } 3 \text { and 5 } & \text { Pt-1-79 } & \text { Neogondolella sp. } \\ \text { PI. 1, Figs. } 4 \text { and } 8 & \text { Pt-2-79 } & \text { Neogondolella elongata } \\ \text { PI. 1, Figs. } 11 \text { and14 } & \text { Pt-2-79 } & \text { Neogondolella elongata } \\ \text { PI. 1, Fig. } 19 & \text { Pt-2-79 } & \text { Neospathodus cristagalli } \\ \text { Reinodden section } & & \\ \text { Pl. 1, Fig. } 1 & \text { Rn-7-79 } & \text { Neospathodus dieneri } \\ \text { PI. 2, Fig. } 6 & \text { Rn-7-79 } & \text { Ellisonia triassica } \\ \text { PI. 1, Fig. } 22 & \text { Rn-8-79 } & \text { Neospathodus cristagalli } \\ \text { PI. 2, Fig. } 8 & \text { Rn-8-79 } & \text { Neogondolella sp. A } \\ \text { PI. 1, Fig. } 20 & \text { Rn-9-79 } & \text { Neospathodus svalbardensis }\end{array}$

Tvillingodden Formation (Sticky Keep Formation), Kaosfjellet Member

Reinodden section

$\begin{array}{lll}\text { Pl. 2, Fig. } 11 & \text { Rn-29-79 } & \text { Neogondolella mombergensis } \\ \text { Pl. 2, Fig. } 13 & \text { Rn-29-79 } & \text { Neogondolella mombergensis }\end{array}$

Tvillingodden Formation (Sticky Keep Formation), Iskletten Member

Pitnerodden section

Pl. 2, Fig. 7

PI. 2, Figs. 14 and 15

PI. 1, Fig. 2

Pl. 1, Fig. 9

PI. 1, Figs. 12 and 13

PI. 1, Fig. 18

PI. 1, Figs. 15 and 16

PI. 2, Figs. 16 and 18

Pl. 2, Fig. 17

PI. 2, Figs. 1 and 4

Botneheia Formation

Reinodden section

PI. 2, Fig. 12

Pitnerodden section

PI. 1, Fig. 10

Pt-4-79

Pt-4-79

Pt-7a-79

Pt-7a-79

Pt-7a-79

Pt-7a-79

Pt-7a-79

Pt-7a-79

Pt-7a-79

Pt-7b-79

Rn-30-79

Pt-17-79
Ellisonia triassica

Neogondolella nevadensis

Neospathodus homeri

Neospathodus homeri

Neospathodus homeri

Neospathodus homeri

Neospathodus sp. aff. triangularis

Neospathodus collinsoni

Neospathodus sp.

Neogondolella jubata

Neogondolella regale

Neogondolella elongata
Revision by M.J. Orchard

\author{
Neospathodus dieneri \\ Ellisonia triassica \\ Merrillina? peculiaris \\ Scythogondolella? sp. \\ ?Scythogondolella? sp. nov. A \\ ?Neospathodus pakistanensis \\ Borinella sp. \\ ?Scythogondolella? sp. nov. A \\ Borinella sp. \\ Neospathodus cristagalli \\ Neospathodus dieneri \\ Ellisonia triassica \\ Neospathodus cristagalli \\ Neogondolella? sp. indet. \\ ?Neospathodus pakistanensis
}

?Neogondolella ex. gr. regalis Neogondolella sp. indet.

ramiform indet.

Scythogondolella mosheri

?Neospathodus waageni

?

?Neospathodus pakistanensis

?

?Neospathodus dieneri

Eurygnathodus? sp

?Neospathodus pakistanensis

Borinella aff. buurensis

Neogondolella ex. gr. regalis

?

Borinella buurensis

Borinella buurensis?

Scythogondolella milleri Scythogondolella mosheri Neospathodus waageni 


\section{Appendix 2}

Taxa mentioned in the text are listed below. See Orchard (2008) for further taxonomic revisions of the conodonts.

\section{Conodonts}

Borinella aff. nepalensis (Kozur \& Mostler, 1976)

Borinella buurensis (Dagis, 1984)

Chiosella cf. timorensis (Nogami, 1968)

Columbitella? paragondolellaeformis (Dagis, 1984)

Ellisonia triassica Müller, 1956

Eurygnathodus sp.

Hindeodus parvus (Kozur \& Pjatakova, 1976)

Merrillina? peculiaris (Sweet, 1970a) (formerly Neospathodus)

Metapolygnathus cf. lobatus Orchard, 2007

Metapolygnathus ex. gr. polygnathiformis (Budurov \& Stefanov, 1965)

Neogondolella carinata (Clark, 1959)

Neogondolella ex. gr. regalis Mosher, 1970

Neogondolella haslachensis trammeri Kozur in Kozur \& Mock (1972)

Neogondolella hauschkei (Kozur, 2004)

Neogondolella jubata Sweet, 1970a

Neogondolella liardensis Orchard, 2007

Neogondolella longa (Budurov \& Stefanov, 1965)

Neogondolella cf. meishanensis (Zhang, Lai, Ding \& Liu, 1995)

Neogondolella mombergensis (Tatge, 1956)

Neogondolella cf. orchardi (Mei, 1996)

Neogondolella sweeti Dagis \& Korčinskaja, 1989 (=Scythogondollella sweeti)

Neogondolella aff. taylorae Orchard, 1994

Neogondolella transita Kozur \& Mostler, 1971

Neogondolella ex. gr. constricta (Mosher \& Clark, 1965)

Neogondolella spitzbergensis Dagis \& Korčinskaja, 1989

Neogondolella aff. composita Dagis, 1984

Neospathodus cf. triangularis (Bender, 1970)

Neospathodus collinsoni Solien, 1979

Neospathodus dieneri Sweet, 1970a
Neospathodus homeri (Bender, 1970)

Neospathodus svalbardensis Trammer, 1978

Neospathodus waageni Sweet, 1970a

Neospathodus aff. cristagalli (Huckriede, 1958)

Neospathodus pakistanensis Sweet, 1970a

Scythogondolella milleri (Müller, 1956)

Scythogondolella mosheri (Kozur \& Mostler, 1976)

\section{Ammonoids}

Anawasatchites tardus (McLearn, 1945)

Arctoceras blomstrandi (Lindström, 1865)

Arctoprionites nodosus (Frebold, 1930)

Aristoptychites euglyphus (Mojsisovics, 1886)

Glyptophiceras nielseni Spath, 1935

Indigirophyllites spetsbergensis (Öberg, 1877)

Keyserlingites subrobustus (Mojsisovics, 1886)

Ophiceras (Acanthophiceras) sp. cf. poulseni Spath, 1935

Ophiceras (Lytophiceras) sp. cf. compressum Spath, 1935

Ophiceras (Lytophiceras) sp. cf. kochi Spath, 1935

Ophiceras (Lytophiceras) spathi Trümpy, 1969

Otoceras boreale Spath, 1935

Paravishnuites oxynotus Spath, 1935

Paravishnuites paradigma Trümpy, 1969

Proptychites cf. candidus Tozer, 1961

Proptychites cf. strigatus Tozer, 1961

Proptychites rosenkrantzi Spath, 1930

Proptychites simplex Spath, 1935

Svalbardiceras spitzbergense Frebold, 1930

Tompophiceras cf. gracile (Spath, 1935)

Unionites sp. cf. breviformis Spath, 1935

Vavilovites spitzbergensis Korčinskaja, 1986

Xenoceltites subevolutus Spath, 1934

\section{Other}

Bellerophon borealis Spath, 1930

Claraia stachei Bittner, 1901

Posidonia aranea Tozer, 1961

Promyalina degeeri Lundgren, 1887 